\title{
HUBUNGAN MOTIVASI PERAWAT DENGAN KELENGKAPAN DOKUMENTASI PENGKAJIAN KEPERAWATAN
}

\author{
Leni Wijaya ${ }^{1}$, Vebriansyah ${ }^{2}$ \\ 1,2 Program Studi S-I Keperawatan STIKES Mitra Adiguna Palembang \\ Jl. Komplek Kenten Permai Blok J 9 - 12 Bukit Sangkal Palembang \\ Email : leniwijaya1408@gmail.com
}

\begin{abstract}
Abstrak
Dokumentasi keperawatan merupakan suatu catatan yang memuat seluruh data yang berhubungan dengan pasien yang sedang dirawat. Data-data itu dibutuhkan untuk menentukan diagnosis keperawatan, serta untuk menentukan berbagai perencanaan tindakan keperawatan. Untuk mendorong perawat dalam melakukan dokumentasi dibutuhkan motivasi sehingga pemberian asuhan keperawatan pada pasien berkesinambungan, tepat sehingga mampu meningkatkan status kesehatan pasien dan meningkatkan kualitas kerja yang dihasilkan sehingga timbul kepuasan dari pelanggan dan pihak rumah sakit. Tujuan penelitian untuk mengetahui hubungan motivasi perawat dengan kelengkapan dokumentasi pengkajian keperawatan di Rumah Sakit Ar Royyan Indralaya Tahun 2021. Metode penelitian yang digunakan adalah metode analitik dengan pendekatan cross sectional dengan jumlah sampel sebanyak 16 orang. Hasil penelitian didapatkan ada hubungan yang bermakna antara motivasi perawat dengan kelengkapan dokumentasi pengkajian keperawatan di Rumah Sakit Ar Royyan Indralaya tahun 2021 dengan nilai $p$ value $=0,035$ dan nilai $O R$ didapatkan $=20$ yang artinya perawat yang kurang mendapatkan motivasi dari atasan cenderung akan melakukan pendokumentasian yang tidak lengkap sebesar 20 kali dibandingkan dengan perawat yang mendapatkan motivasi yang baik dari atasan. Saran diharapkan pihak rumah sakit dapat lebih meningkatkan lagi motivasi kepada perawat khususnya dalam melakukan pendokumentasian asuhan keperawatan. Sehingga diharapkan dapat meningkatkan kinerja perawat dalam melakukan pendokumentasian pengkajian keperawatan.
\end{abstract}

\section{Kata kunci : Motivasi Perawat, Kelengkapan Dokumentasi Pengkajian Keperawatan}

\begin{abstract}
Abstrack
Nursing documentation is a record that contains all data related to the patient being treated. These data are needed to determine nursing diagnoses, as well as to determine various nursing action plans. To encourage nurses to do documentation, motivation is needed so that the provision of nursing care to patients is continuous, appropriate so as to improve the health status of patients and improve the quality of work produced so that satisfaction arises from customers and the hospital. The purpose of the study was to determine the relationship between nurses' motivation and the completeness of nursing assessment documentation at Ar Royyan Indralaya Hospital in 2021. The research method used was an analytical method with a cross sectional approach with a total sample of 16 people. The results showed that there was a significant relationship between the motivation of nurses and the completeness of documentation of nursing assessments at Ar Royyan Indralaya Hospital in 2021 with a p value $=0.035$ and an $O R$ value $=20$, which means that nurses who lack motivation from superiors tend to do documentation that does not complete by 20 times compared to nurses who get good motivation from superiors. Suggestions are expected that the hospital can further increase the motivation of nurses, especially in documenting nursing care. So that it is expected to improve the performance of nurses in documenting nursing assessments.
\end{abstract}

Keywords : Nurse Motivation, Completeness of Nursing Assessment Documentation 


\section{PENDAHULUAN}

Pelayanan keperawatan merupakan pelayanan profesional, sebagai bagian integral dari pelayanan kesehatan yang mempunyai daya ungkit besar terhadap pembangunan bidang kesehatan. Kualitas pelayanan kesehatan ditentukan salah satunya dari kualitas pelayanan keperawatan yang diberikan oleh perawat yang berkualitas (PPNI dalam Wisuda, 2019). Peningkatan mutu pelayanan keperawatan diberikan dalam bentuk kinerja perawat dan harus didasari kemampuan yang tinggi sehingga kinerja mendukung pelaksanaan tugas dalam pelayanan keperawatan. Kinerja merupakan suatu hasil kerja seseorang yang dilakukan sesuai dengan tugas dalam suatu organisasi (Nursalam dalam Wisuda, 2019).

Asuhan keperawatan merupakan salah satu indikator dalam menentukan kualitas pelayanan dari suatu rumah sakit. Perawat merupakan profesi yang memberikan pelayanan keperawatan kepada pasien, dimana salah satu aspek terpenting kinerja adalah pendokumentasian asuhan keperawatan (Nursalam dalam Hendayani, 2019).

Organisasi kesehatan dunia (WHO) melaporkan bahwa sekarang ada lebih dari 9 juta perawat dan bidan dari 141 negara. Sedangkan menurut data Kementrian Kesehatan RI (2014) jumlah perawat di Indonesia tahun 2013 yaitu 288.405 orang. Keperawatan sebagai suatu profesi di rumah sakit yang cukup potensial dalam menyelenggarakan upaya mutu, karena selain jumlah perawat yang dominan di rumah sakit juga pelayanannya menggunakan metode pemecahan masalah secara ilmiah melalui pendokumentasian proses keperawatan (Kemenkes dalam Hendayani, 2019).

Masalah yang sering muncul dan dihadapi di Indonesia dalam pelaksanaan asuhan keperawatan adalah banyak perawat yang belum melakukan pelayanan sesuai pendokumentasian asuhan keperawatan. Pelaksanaan asuhan keperawatan juga tidak disertai pendokumentasian yang lengkap. Fakta menunjukkan bahwa dari 10 dokumentasi asuhan keperawatan, dokumentasi pengkajian hanya terisi (25\%), dokumentasi diagnosis keperawatan (50\%), dokumentasi perencanaan (37,5\%), dokumentasi implementasi $(35,5 \%)$ dan dokumentasi evaluasi (25\%) (Indrajati dalam Hendayani, 2019).

Dokumentasi adalah sebuah komunikasi tertulis yang secara permanen mendokumentasikan berbagai informasi yang relevan terhadap berbagai pengaturan kesehatan pasien. Dokumentasi juga merupakan catatan yang sah dan legal yang berhubungan dengan pemeriksaan pasien, proses diagnosa, perencanaan, proses implementasi dan evaluasi (Prabowo, 2018:40).

Dokumentasi keperawatan merupakan bukti pencatatan dan pelaporan yang dimiliki tenaga kesehatan. Pencatatan dokumentasi keperawatan itu berguna untuk kepentingan pasien, para perawat serta seluruh tim kesehatan yang bekerja memberikan pelayanan kesehatan kepada satu orang pasien itu. Catatan itu disusun berdasarkan komunikasi yang akurat antara pasien serta tenaga keperawatan. Catatan itu juga disusun dengan lengkap dan secara tertulis. Yang bertanggung jawab atas catatan tersebut adalah si perawat yang melakukan proses pendokumentasian (Hidayat dalam Prabowo, 2018:41).

Dokumentasi asuhan keperawatan menggunakan pendekatan proses keperawatan yang terdiri dari pengkajian, perumusan diagnosa, perencanaan, pelaksanaan, dan evaluasi sebagai metode ilmiah penyelesaian masalah keperawatan pada pasien untuk meningkatkan outcome pasien. Ciri dokumentasi asuhan keperawatan yang baik adalah berdasarkan fakta (factual basis), akurat (accuracy), lengkap (completeness), ringkas 
(conciseness), terorganisir (organization), waktu yang tepat (time liness), dan bersifat mudah dibaca (legability). Prinsip-prinsip pendokumentasian direvisi menjadi tiga bentuk standar dokumentasi yaitu communication, accountability, dan safety (Lestari, 2019).

Pelaksanaan dokumentasi keperawatan terdapat banyak hal yang dapat mempengaruhi perawat dalam melaksanakannya. Hal ini terkait dengan tingkat pendidikan, pengetahuan, motivasi, dan waktu untuk mendukung pelaksanaan dokumentasi asuhan keperawatan yang lebih akurat (Hidayat dalam Artanti, 2020). Keinginan, dorongan dan kebutuhan setiap orang dalam melakukan sesuatu tindakan berbeda, kekuatan motivasi seseorang akan menentukan kualitas kegiatan yang dilakukan. Untuk pendokumentasian asuhan keperawatan sangat dibutuhkan motivasi yang baik dari seorang perawat yang muncul sepenuhnya dari hati dan untuk menimbulkan motivasi tersebut maka seorang perawat perlu menyadari kebutuhan dan kepentingan pendokumentasian asuhan keperawatan dan kurangnya kesadaran dari perawat akan pentingnya dokumentasi keperawatan dapat menyebabkan pencatatan terkadang tidak lengkap (Nettina dalam Artanti, 2020).

Motivasi adalah salah satu faktor menentukan hasil kerja seseorang termotivasi dalam berkerja berusaha sekuat tenaga untuk mengwujudkan dan menyelesaikan tugasnya. Motivasi dipastikan mempengaruhi kinerja walaupun bukan salah satunya faktor yang membentuk kinerja (Hendayani, 2019).

Keberadaan motivasi sangat diperlukan untuk mendorong perawat dalam melakukan dokumentasi sehingga pemberian asuhan keperawatan pada pasien berkesinambungan, tepat sehingga mampu meningkatkan status kesehatan pasien dan meningkatkan kualitas kerja yang dihasilkan sehingga timbul kepuasan dari pelanggan dan pihak rumah sakit. Adanya kepuasan kerja diharapkan akan menciptakan hubungan kerja yang harmonis antara karyawan dan pimpinan sehingga tujuan rumah sakit dapat tercapai dan berhasil secara optimal (Sari dalam Hendayani, 2019). Motivasi merupakan suatu proses dimana kebutuhan-kebutuhan mendorong seseorang untuk melakukan serangkaian kegiatan yang mengarah ke tercapainya suatu tujuan tertentu (Mangkunegara dalam Hendayani, 2019). Pentingnya motivasi karena motivasi adalah hal yang menyebabkan, menyalurkan, dan mendukung prilaku manusia supaya mau bekerja giat dan antusias mencapai hasil yang optimal (Hasibuan dalam Hendayani, 2019).

Perawat yang mempunyai motivasi tinggi untuk mencapai mutu pelayanan keperawatan yang baik yaitu dengan melakukan dokumentasi keperawatan. Hal ini sesuai dengan Koontz dalam Lestari (2019) yang menyatakan bahwa motivasi mengacu pada dorongan dan usaha untuk merumuskan kebutuhan atau suatu tujuan. Motivasi yang semakin tinggi menjadikan perawat mempunyai semangat yang tinggi untuk memberikan pelayanan yang terbaik (Mudayana dalam Lestari, 2019).

Menurut penelitian yang dilakukan oleh Berthiana (2012) tentang hubungan motivasi kerja dengan mutu pendokumentasian asuhan keperawatan di ruang rawat inap RSUD Buntok, didapatkan hasil adanya hubungan yang positip antara motivasi kerja perawat dengan ketepatan pengisian dokumentasi asuhan keperawatan dan hubungan tersebut bermakna statistik yaitu semakin tinggi motivasi seorang perawat akan mempengaruhi kelengkapan dokumentasi asuhan keperawatan.

Berdasarkan hasil penelitian Medinawati (2019) tentang Hubungan Motivasi Kerja Perawat Dengan Kepatuhan Pendokumentasian Implementasi Asuhan Keperawatan Di RSU Yarsi Pontianak. Penelitian kuantitatif menggunakan desain penelitian cross sectional. Hasil penelitian 
ini menunjukan terdapat hubungan antara motivasi kerja perawat dengan kepatuhan pendokumentasian implementasi asuhan keperawatan di RSU YARSI Pontianak dengan nilai signifikasi menunjukan nilai $p$ value $=0,011<\alpha 0,05$ yang berarti $\mathrm{Ha}$ diterima.

Penelitian serupa oleh Pakudek (2019) yang berjudul Hubungan Motivasi Perawat Dengan Pelaksanaan Dokumentasi Asuhan Keperawatan Di Instalasi Rawat Inap C RSUP Prof. Dr. R. D. Kandou Manado. Penelitian ini menggunakan metode survey dengan pendekatan Cross Sectional. Hasil penelitian: Dari 51 responden, yang memiliki motivasi intrinsik baik dan melakukan dokumentasi dengan lengkap sebanyak 43 orang, dan yang memiliki motivasi kurang dan melakukan dokumentasi tidak lengkap sebanyak 3 orang. Hasil uji statistik didapatkan ada hubungan yang bermakna antara motivasi perawat dengan pelaksanaan dokumentasi asuhan keperawatan di instalasi rawat inap C RSUP Prof. Dr. R. D. Kandou Manado dengan nilai $p$ value $=0,003$.

Berdasarkan data yang didapat dari Rumah Sakit Ar Royyan Indralaya, jumlah tenaga kerja perawat pada tahun 2020 sebanyak 16 orang dengan 4 ruang rawat inap (Rumah Sakit Ar Royyan Indralaya, 2021).

Dari hasil survei awal peneliti mendapatkan data rekam medis dari empat ruangan rawat inap yang ada di Rumah Sakit Ar Royyan Indralaya yaitu ruangan ArRahim, Ar-Rahmah, Ar-Raudah, ArRahmah, angka tertinggi pendokumentasian yang tidak lengkap di dapatkan di ruangan Ar-Rahim. Peneliti melakukan wawancara dengan 8 perawat yang ada di 4 ruangan tersebut dengan mengambil tiap ruangan 2 orang perawat. Dari hasil wawancara di dapatkan bahwa dari 8 orang perawat yang dilakukan wawancara 5 (lima) orang diantaranya mengatakan bahwa kurangnya motivasi perawat dalam mengisi pendokumentasian asuhan keperawatan dan dari obsevasi hasil pendokumentasian asuhan keperawatan yang dilakukan perawat sebanyak 5 (lima) diantaranya tidak terisi lengkap. Karena tidak ada supervisi kepala ruangan terhadap pelaksanaan pendokumentasian asuhan keperawatan, perawat beranggapan bahwa pendokumentasian tersebut tidak penting. Berdasarkan latar belakang diatas, peneliti tertarik untuk melakukan penelitian dengan judul "Hubungan Motivasi Perawat dengan Kelengkapan Dokumentasi Pengkajian Keperawatan di Rumah Sakit Ar Royyan Indralaya Tahun 2021”.

\section{METODE PENELITIAN}

Pada penelitian ini peneliti menggunakan metode analitik dengan pendekatan cross sectional. Metode analitik adalah penelitian yang mencoba menggali bagaimana fenomena kesehatan itu terjadi. Kemudian melakukan analisis dinamika korelasi antara fenomena antara faktor risiko (motivasi perawat) dengan faktor efek (kelengkapan dokumentasi keperawatan). Sedangkan pendekatan cross sectional ialah suatu penelitian untuk mempelajari dinamika korelasi antara faktor-faktor resiko dengan efek, dengan cara pendekatan, observasi atau pengumpulan data sekaligus pada suatu saat (point time approach) (Notoatmodjo, 2018).

Penelitian ini dilaksanakan di Rumah Sakit Ar Royyan Indralaya Palembang pada tanggal 5 - 10 April 2021. Populasi pada penelitian ini adalah seluruh perawat yang ada di Ruang Rawat Inap Rumah Sakit Ar Royyan Indralaya yang berjumlah 16 orang. Sampel pada penelitian ini adalah menggunakan teknik sampel jenuh atau total populasi dan alat ukur yang digunakan adalah kuesioner.

Teknik pengumpulan data pada penelitian ini menggunakan kuesioner sebagai alat bantu dalam pengambilan data motivasi perawat dan obeservasi untuk 
melihat kelengkapan dokumentasi keperawatan.

Tehnik pengolahan data setelah data terkumpul secara manual kemudian di olah dengan menggunakan komputer melalui beberapa tahap antara lain; editing, coding, proccessing, dan cleaning. Analisis data menggunakan analisis univariat dan analisis bivariat.

\section{HASIL PENELITIAN}

Analisa Univariat

Analisa ini dilakukan untuk mengetahui distribusi frekuensi dan persentase dari variabel independen (motivasi perawat) dan variabel dependen (kelengkapan dokumentasi pengkajian keperawatan).

Tabel 1

\section{Distribusi Frekuensi Responden Berdasarkan Karakteristik Perawat di Rumah Sakit Rumah Sakit Ar Royyan Indralaya Tahun 2021}

\begin{tabular}{|c|l|l|c|c|}
\hline No & & \multicolumn{1}{|c|}{ Variabel } & Frekuensi & $\%$ \\
\hline 1. & Jenis Kelamin & Laki-laki & 3 & 18,8 \\
& & Perempuan & 13 & 81,2 \\
\hline 2. & Umur & 21-25 tahun & 3 & 18,8 \\
& & 26-35 tahun & 10 & 62,4 \\
& & 36-45 tahun & 3 & 18,8 \\
\hline 3. & Pendidikan & 46-55 tahun & 0 & 0 \\
& & DIII Keperawatan & 13 & 81,3 \\
& & DIV Keperawatan & 1 & 6,2 \\
& & S1 Keperawatan & 2 & 12,5 \\
\hline 4. & Lama Kerja & S2 Keperawatan & 0 & 0 \\
& & 1-5 tahun & 16 & 0 \\
& & 6-10 tahun & 0 & 0 \\
& & 11-15 tahun & 0 & 0 \\
\hline 5. & Kelengkapan & Lengkap & 9 & 56,3 \\
& Dokumentasi & Tidak Lengkap & 7 & 43,7 \\
& Pengkajian & & & \\
& Keperawatan & & 10 & 62,5 \\
\hline 6. & Motivasi & Baik & 6 & 37,5 \\
\hline
\end{tabular}

Pada tabel di atas dapat dilihat bahwa sebagian besar responden yang berjenis kelamin perempuan sebanyak 13 orang $(81,2 \%)$, responden berusia $26-35$ tahun sebanyak 10 orang $(62,4 \%)$, responden yang berpendidikan DIII Keperawatan sebanyak 13 orang $(81,3 \%)$, responden memiliki lama kerja 1-5 tahun sebanyak 16 orang $(100 \%)$, kelengkapan dokumentasi pengkajian keperawatan sebagian besar pada kategori lengkap sebanyak 9 responden $(56,3 \%)$ motivasi kategori baik sebanyak 10 responden $(62,5)$.

\section{Analisa Bivariat}


Analisa ini dilakukan untuk mengetahui hubungan antara variabel independen (motivasi perawat) dan variabel dependen (kelengkapan dokumentasi pengkajian keperawatan). Penelitian ini menggunakan uji statistik Chi Square. Menggunakan sistem komputerisasi Statistical Program for Social Science (SPSS) versi 20 dengan batas kemaknaan pada $\alpha=0,05$. Jika $p$ value $\leq \alpha$ $=0,05$ artinya ada hubungan yang bermakna (signifikan) antara variabel independen dan variabel dependen, jika $p$ value $>\alpha=0,05$

\section{Hubungan Motivasi Perawat Terhadap Kelengkapan Dokumentasi Pengkajian Keperawatan}

Tabel 2

Hubungan Motivasi Perawat Terhadap Kelengkapan Dokumentasi Pengkajian Keperawatan di Rumah Sakit Rumah Sakit Ar Royyan Indralaya Tahun 2021

\begin{tabular}{|c|c|c|c|c|c|c|c|c|c|}
\hline \multirow{3}{*}{ No } & \multirow{3}{*}{$\begin{array}{r}\text { Motivasi } \\
\text { Perawat }\end{array}$} & \multicolumn{4}{|c|}{$\begin{array}{l}\text { Kelengkapan Dokumentasi } \\
\text { Pengkajian Keperawatan }\end{array}$} & \multirow{3}{*}{$\mathrm{N}$} & \multirow{3}{*}{$\%$} & \multirow{3}{*}{$\begin{array}{c}p \\
\text { value }\end{array}$} & \multirow{3}{*}{$O R$} \\
\hline & & \multicolumn{2}{|c|}{ Lengkap } & \multicolumn{2}{|c|}{$\begin{array}{l}\text { Tidak } \\
\text { Lengkap }\end{array}$} & & & & \\
\hline & & $\mathrm{n}$ & $\%$ & $\mathrm{n}$ & $\%$ & & & & \\
\hline 1. & Baik & 8 & 80 & 2 & 20 & 10 & 100 & & \\
\hline 2. & Kurang & 1 & 16,7 & 5 & 83,3 & 6 & 100 & 0,035 & 20 \\
\hline & Total & 9 & & 7 & & 16 & & & \\
\hline
\end{tabular}

Berdasarkan tabel 4.7 diatas diketahui bahwa dari 10 responden mendapatkan motivasi kategori baik sebagian besar melakukan dokumentasi pengkajian keperawatan secara lengkap sebanyak 8 responden (80\%). Sedangkan dari 6 responden yang kurang mendapatkan motivasi sebagian besar melakukan dokumentasi pengkajian keperawatan secara tidak lengkap sebanyak 5 responden $(83,3 \%)$.

Dari hasil uji Chi-Square didapatkan nilai $p$ value $=0,035<\alpha(0,05)$ hal ini menunjukkan bahwa ada hubungan yang bermakna antara motivasi perawat dengan kelengkapan dokumentasi pengkajian keperawatan di Rumah Sakit Rumah Sakit Ar Royyan Indralaya tahun 2021. Sedangkan nilai $\mathrm{OR}=20$ yang artinya perawat yang artinya tidak ada hubungan yang bermakna (signifikan) antara variabel independen dan variabel dependen. 
motivasi sebagian besar melakukan dokumentasi pengkajian keperawatan secara tidak lengkap sebanyak 5 responden $(83,3 \%)$.

Dari hasil uji Chi-Square didapatkan nilai $p$ value $=0,035<\alpha(0,05)$ hal ini menunjukkan bahwa ada hubungan yang bermakna antara motivasi perawat dengan kelengkapan dokumentasi pengkajian keperawatan di Rumah Sakit Rumah Sakit Ar Royyan Indralaya tahun 2021. Sedangkan nilai $\mathrm{OR}=20$ yang artinya perawat yang kurang mendapatkan motivasi dari atasan cenderung akan melakukan pendokumentasian yang tidak lengkap sebesar 20 kali dibandingkan dengan perawat yang mendapatkan motivasi yang baik dari atasan. Dengan demikian hipotesa awal yang menyatakan ada hubungan yang bermakna antara motivasi perawat dengan kelengkapan dokumentasi pengkajian keperawatan di Rumah Sakit Rumah Sakit Ar Royyan Indralaya tahun 2021 terbukti secara statistik.

Hal ini sesuai dengan hasil survei awal peneliti mendapatkan data rekam medis dari empat ruangan rawat inap yang ada di Rumah Sakit Ar Royyan Indralaya yaitu ruangan Ar-Rahim, Ar-Rahmah, Ar-Raudah, Ar-Rahmah, angka tertinggi pendokumentasian yang tidak lengkap di dapatkan di ruangan Ar-Rahim. Peneliti melakukan wawancara dengan 8 perawat yang ada di 4 ruangan tersebut dengan mengambil tiap ruangan 2 orang perawat. Dari hasil wawancara di dapatkan bahwa dari 8 orang perawat yang dilakukan wawancara 5 (lima) orang diantaranya mengatakan bahwa kurangnya motivasi perawat dalam mengisi pendokumentasian asuhan keperawatan dan dari obsevasi hasil pendokumentasian asuhan keperawatan yang dilakukan perawat sebanyak 5 (lima) diantaranya tidak terisi lengkap. Karena tidak ada supervisi kepala ruangan terhadap pelaksanaan pendokumentasian asuhan keperawatan, perawat beranggapan bahwa pendokumentasian tersebut tidak penting.
Hal ini sesuai dengan pernyataan Artanti (2020), yang menyatakan bahwa untuk pendokumentasian asuhan keperawatan sangat dibutuhkan motivasi yang baik dari seorang perawat yang muncul sepenuhnya dari hati dan untuk menimbulkan motivasi tersebut maka seorang perawat perlu menyadari kebutuhan dan kepentingan pendokumentasian asuhan keperawatan dan kurangnya kesadaran dari perawat akan pentingnya dokumentasi keperawatan dapat menyebabkan pencatatan terkadang tidak lengkap.

Lebih lanjut menurut Artanti (2020), menyatakan bahwa semakin rendahnya motivasi responden maka tingkat kelengkapan dokumentasi pengkajian keperawatan juga rendah, sebaliknya tingginya motivasi pada responden maka tingkat kelengkapan dokumentasi pengkajian keperawatan juga tinggi. Motivasi yang rendah mempengaruhi perawat di dalam kepatuhan mendokumentasikan hasil dari pengkajian keperawatan yang dilakukan. Sehingga dapat menurunkan mutu keperawatan dan mutu rumah sakit. Hal tersebut dapat terjadi karena kurangnya pemahaman perawat akan pentingnya dokumentasi dari pengkajian keperawatan yang telah dilakukan oleh perawat. Salah satu indikator kinerja perawat dalam melaksanakan pengkajian keperawatan bisa dilihat dari pelaksanaan pendokumentasian. Tanpa dokumentasi keperawatan maka semua implementasi keperawatan yang telah dilakukan oleh perawat tidak mempunyai makna dalam hal tanggung jawab dan tanggung gugat.

Hal serupa diungkapkan Hendayani (2019), yang menyatakan bahwa keberadaan motivasi sangat diperlukan untuk mendorong perawat dalam melakukan dokumentasi sehingga pemberian asuhan keperawatan pada pasien berkesinambungan, tepat sehingga mampu meningkatkan status kesehatan pasien dan meningkatkan kualitas kerja yang dihasilkan sehingga timbul 
kepuasan dari pelanggan dan pihak rumah sakit. Adanya kepuasan kerja diharapkan akan menciptakan hubungan kerja yang harmonis antara karyawan dan pimpinan sehingga tujuan rumah sakit dapat tercapai dan berhasil secara optimal. Pentingnya motivasi karena motivasi adalah hal yang menyebabkan, menyalurkan, dan mendukung prilaku manusia supaya mau bekerja giat dan antusias mencapai hasil yang optimal.

Lebih lanjut menurut Alimuddin dalam Hendayani (2019), menerangkan bahwa motivasi berperan sangat penting dalam meningkatkan kinerja karyawan. Tujuan dalam memberikan motivasi kerja terhadap karyawan agar karyawan dapat melaksanakan tugasnya secara efektif dan efisien. Dengan demikian berarti juga mampu memelihara dan meningkatkan moral, semangat dan gairah kerja, karena dirasakan sebagai pekerjaan yang menantang. Program dengan cara ini suatu organisasi dapat mendorong berkembangnya motivasi berprestasi dalam suatu perusahaan, yang akan memacu tumbuh dan berkembangnya persaingan sehat antara individu atau tim kerja dalam suatu perusahaan. Tetapi dalam individu setiap manusia tidak semua karyawan termotivasi lewat lingkungan kerjanya yang biasa disebut dengan motivasi eksternal, tetapi ada juga karyawan yang termotivasi dari dalam dirinya sendiri (motivasi internal) tanpa ada motivasi khusus yang dia dapatkan dalam lingkungan kerjanya.

Hasil penelitian ini sejalan dengan penelitian penelitian Medinawati (2019) tentang Hubungan Motivasi Kerja Perawat Dengan Kepatuhan Pendokumentasian Implementasi Asuhan Keperawatan Di RSU Yarsi Pontianak. Penelitian kuantitatif menggunakan desain penelitian cross sectional. Hasil penelitian ini menunjukan terdapat hubungan antara motivasi kerja perawat dengan kepatuhan pendokumentasian implementasi asuhan keperawatan di RSU YARSI Pontianak dengan nilai signifikasi menunjukan nilai $p$ value $=0,011<\alpha 0,05$ yang berarti $\mathrm{Ha}$ diterima.

Penelitian serupa oleh Pakudek (2019) yang berjudul Hubungan Motivasi Perawat Dengan Pelaksanaan Dokumentasi Asuhan Keperawatan Di Instalasi Rawat Inap C RSUP Prof. Dr. R. D. Kandou Manado. Penelitian ini menggunakan metode survey dengan pendekatan Cross Sectional. Hasil penelitian: Dari 51 responden, yang memiliki motivasi intrinsik baik dan melakukan dokumentasi dengan lengkap sebanyak 43 orang, dan yang memiliki motivasi kurang dan melakukan dokumentasi tidak lengkap sebanyak 3 orang. Hasil uji statistik didapatkan ada hubungan yang bermakna antara motivasi perawat dengan pelaksanaan dokumentasi asuhan keperawatan di instalasi rawat inap C RSUP Prof. Dr. R. D. Kandou Manado dengan nilai $p$ value $=0,003$.

Berdasarkan hasil pembahasan diatas, peneliti berasumsi bahwa motivasi merupakan kunci utama yang menentukan kinerja perawat dalam hal ini yaitu pelaksanaan dokumentasi keperawatan. Dalam pelaksanaannya perawat harus mempunyai dorongan dan kemauan yang kuat yang berasal dari dalam diri perawat itu sendiri. Kalau perawat tidak memiliki motivasi yang baik maka pelaksanaan dokumentasi keperawatan tidak akan tercapai dan bisa saja hal ini mempengaruhi kualitas pelayanan kesehatan.

\section{KESIMPULAN}

Ada hubungan yang bermakna antara motivasi perawat dengan kelengkapan dokumentasi pengkajian keperawatan di rumah sakit rumah sakit ar royyan indralaya tahun 2021 dengan nilai $p$ value $=0,035$.

\section{SARAN}

Hasil penelitian ini diharapkan dapat lebih meningkatkan lagi motivasi kepada perawat khususnya dalam melakukan 
pendokumentasian asuhan keperawatan. Sehingga diharapkan dapat meningkatkan kinerja perawat dalam melakukan pendokumentasian pengkajian keperawatan serta dalam memberikan pelayanan kepada masyarakat sehingga mutu pelayanan rumah sakit dapat menjadi lebih baik dan mendapatkan kepercayaan dari masyarakat.

\section{DAFTAR PUSTAKA}

Artanty, Evi. 2020. Nurse Motivation Correlation With Documentation Of Nursing Assessment Inpatient Installation In Baptis Batu Hospital. Jurnal Penelitian Keperawatan Vol 6. (2) Agustus 2020, diakses 15 Januari 2021

Berthiana. 2012. Hubungan motivasi kerja dengan mutu pendokumentasian asuhan keperawatan di ruang rawat inap RSUD Buntok. Volume 1, No. 1, Mei 2013; 57-72, diakses 15 Januari 2021

Hendayani, Weni Lidya. 2019. Hubungan Motivasi Perawat Dengan Pendokumentasian Asuhan Keperawatan Di Ruangan Rawat Inap Interne RSUD Kota Padang Panjang. Jurnal Vol. XIII No.5 April 2019, diakses 20 Januari 2021

Lestari, Anissa Wahyu. 2019. Hubungan Motivasi Perawat dengan Pelaksanaan Dokumentasi Keperawatan di Rumah Sakit Islam Sultan Agung Semarang, diakses 15 Januari 2021

Medinawati, Annisa Nur. 2019. Hubungan Motivasi Kerja Perawat Dengan Kepatuhan Pendokumentasian
Implementasi Asuhan Keperawatan Di RSU Yarsi Pontianak, diakses 18 Januari 2021

Medinawati. 2019. Hubungan motivasi kerja perawat dengan kepatuhan Pendokumentasian implementasi asuhan keperawatan di RSU Yarsi Pontianak, diakses 15 Januari 2021

Notoatmodjo, Soekidjo. 2018. Metodologi Penelitian Kesehatan. Jakarta: Rineka Cipta

Nursalam. 2014. Manajemen Keperawatan Aplikasi dalam Praktik Keperawatan Profesional. Jakarta: Salemba Medika

Pakudek, Kriska H. 2019. Hubungan Motivasi Perawat Dengan Pelaksanaan Dokumentasi Asuhan Keperawatan Di Instalasi Rawat Inap C RSUP Prof. Dr. R. D. Kandou Manado, diakses 21 Januari 2021

Prabowo, Tri. 2018. Dokumentasi Keperawatan. Yogyakarta: PT. Pustaka Baru

Rumah Sakit Ar Royyan Indralaya. 2020. Profil Rumah Sakit Ar Royyan Indralaya tahun 2020

Santoso. 2018. Hubungan pengetahuan dan motivasi perawat dengan kinerja pendokumentasian asuhan keperawatan di Pelayanan Rawat Inap Puskesmas Guluk Guluk, diakses 15 Januari 2021

Sugiyono. 2007. Metode Penelitian Kuantitatif Kualitatif dan $R \& D$. Bandung: Alfabeta 
Susiana. 2019. Faktor-faktor yang

berhubungan dengan mutu

pendokumentasian asuhan

keperawatan di RSUD Dr. Soetomo

Surabaya. Skripsi Fakultas

Keperawatan Universitas Airlangga

Surabaya, diakses 20 Januari 2021

Wisuda, Aris Citra. 2019. Kinerja Perawat Pelaksana Dalam Pendokumentasian Asuhan Keperawatan Di Instalasi Rawat Inap. Jurnal Volume 4, Nomor 2, Agustus 2019, diakses 15 Januari 2021 